\title{
Women's trade - a growing concern for the Church Social Thought
}

\author{
Tráfico de mulheres - uma preocupação crescente no
}

Pensamento Social da Igreja

JOSÉ MAIA ${ }^{a}$

MÁRIO ANTONIO SANCHES ${ }^{b}$

\begin{abstract}
The objectives of this article are to address a situation where life is threatened by international trafficking of humans and illustrate some serious concerns of the Church in this matter. This article emerges from experience, since one of the authors acted as a priest of the Catholic Church in East Timor in the border with Indonesia. UN studies show that human trafficking victims' men and women, adults and children, and the sexual exploitation is one of the most dramatic and reported forms of it. The main motivation is economic, and this traffic generates billions of dollars in illegal profits each year. The Roman Catholic Church addressed the issue more clearly in the Second Vatican Council denouncing what was called "trade in women and children". Pope John Paul II situated this practice between the actions that are opposed to life and violate the human integrity. The Pope Francisco situated the problem under the current poor working conditions, as well as in the context of migration and refugees. Thus, human trafficking is an emerging theme in the Church, with concerns rising, appointed as attack on human dignity, crime, exploitation and result of poor working conditions that affects those who live in greater poverty on Earth.
\end{abstract}

Keywords: Trafficking in human. Sexual exploitation. Modern slavery. Human dignity.

a Instituto Superior de Filosofia e Teologia (ISFT), Dili, Timor-Leste, Mestre em Bioética, e-mail: pejemaia@gmail.com

b Pontifícia Universidade Católica do Paraná (PUCPR), Curitiba, PR, Brasil. Doutor em Teologia, e-mail: m.sanches@pucpr.br 


\section{Resumo}

Os objetivos deste artigo são abordar uma situação onde a vida é ameaçada pelo tráfico internacional de humanos e ilustrar algumas preocupações sérias da Igreja em relação a este assunto. Este artigo emerge da experiência visto que um dos autores atuou como padre da Igreja Católica no Timor Leste na área de fronteira com a Indonésia. Estudos da ONU demonstram que o tráfico de humanos faz vítimas entre homens e mulheres, adultos e crianças, sendo um dos aspectos mais dramáticos e mais relatados o da exploração sexual. A principal motivação é econômica e este tráfico gera bilhões de dólares em lucro ilegal a cada ano. A Igreja Católica abordou a questão mais claramente no Concílio Vaticano II denunciando o que foi chamado de "comércio de mulheres e crianças". O Papa João Paulo II situou a questão entre as ações que são a vida e que viola a integridade humana. O Papa Francisco situa a questão também no âmbito das atuais más condições de trabalho, bem como no contexto de migrações e refugiados. Por fim o tráfico humano é um tema emergente na Igreja, com preocupações crescentes, apontado como atentado à dignidade humana, crime, exploração e resultado de más condições de trabalho que atinge os que vivem em maior pobreza na terra.

Palavra-chave: Tráfico humano. Exploração sexual. Escravidão moderna. Dignidade humana.

\section{Introduction}

It is a very important part of the Church's mission, to promote life and defend human dignity when it is threatened. This is because the Church is an heiress of a tradition that professes that the human being was created in the image and likeness of God. The main objective of this article is to address a situation where human life is threatened by international human trafficking.

This research emerges from experience, since one of the authors acted as a priest of the Catholic Church in East Timor in the border with Indonesia. About this, there have been work experiences in a parish near the border, for seven years, with knowledge about the movement of people in this area between East Timor and Indonesia. This people used to present their problems more easily in the Church, to priests and religious sisters, rather than to address local authorities. From this moment on there was a desire to be able to provide a more adequate comprehension of the human trafficking to help people and families of East Timor who suffered being victims of these situations. Therefore, the research emerged from the practical need to provide adequate instruction in order to avoid involvement in this serious problem. 
The United Nation (UN) in its report (2012), in a study on the world economy, detects the problem in both developed and underdeveloped countries. Trafficking human beings is increasing in the least developed countries, and the highest incidence is in women and children, who try to get out of the painful situations in a certain way and end up having even greater problem getting involved in the traffic. The issue has been posed as an international and human rights problem, so the Universal Declaration of Human Rights (UDHR), Article 4, states that: "No one shall be held in slavery or servitude, slavery and the slave trade shall be prohibited in all its forms" (UDHR, 2009, p. 1).

The result of human trafficking is the submission of both men and women to situations of slavery, oppression, contempt, humiliation, forced involvement in situations of pornography and prostitution. These are mainly organized criminal actions and it brings to the victims numerous damages and various discriminations in the personal and well as the family. Globally speaking, the people who suffer the most in these cases are women, adolescents and children, as they are the main victims. Also, in the case of East Timor, women are the most exposed, so, this is the main focus of our work.

This article identifies the issue of human trafficking internationally and seeks to map out the Catholic Church's concern about human trafficking, initially referred to as women trade, identifying that this has been a growing concern.

\section{Trafficking of Women in the World}

Human Trafficking continues to be a current issue in Est Timor and internationally, even if it is almost unanimous condemnation by local and international leaders. This reveals two main aspects: the seriousness with which the government deals with the subject, and the situation of helplessness of the people victimized by this crime. Thus, from the ethical point of view, it can be said that this practice is done against human dignity.

According to UN statistics (2016), more than 2 million people are victims of human trafficking each year. In Europe 21 million traffics, sexual exploitation, forced 
labor and other activities of this nature. And the economy of this "trade" generates around 117 billion euros per year (CAZARRÉ, 2016, p. 1).

The United Nations Office on Drugs and Crime (UNODC), which presents the Global Report on Trafficking in Persons, attempted, for the first time in April 2006, to identify patterns of human trafficking. In 2009, in the second report, based on criminal justice data and victim assistance from 155 countries, it cataloged and analyzed the global response to this problematic event (UNODC, 2009, p. 6). In the 2009 report, $\mathrm{UNODC}^{3}$ presented five major points, such as the following:

The first point is that from 2006 to 2009, it has doubled the number of countries that have taken steps to implement the main international agreement on combating human trafficking with the UN Protocol. However, some countries still lack the necessary legal instruments to combat them.

In the second point, it is observed that there is an increase in the number of convictions, although it is not a proportional increase, and there is a conviction that condemnation occurs only in some countries. The Report says that where the problem is more serious is not where it is more condemned. It points out that in 2007/08 two countries, out of five covered by this report, did not register a single conviction. With regard to this point, the document states and exhorts with emphasis: Either they are blind to the problem, or ill-equipped to deal with it. It calls on governments and other stakeholders to draw on UNODC's expertise, including the recently published Toolkit to combat trafficking in persons, to demonstrate their commitment.

In the third point, it presents a statistical result according to which, sexual exploitation is a more common form of trafficking in human beings (79\%), followed by forced labor (18\%). This may be the result of statistical bias. In general, the exploitation of women tends to be visible, in city centers or on highways. As it is most often reported, sexual exploitation has become the most documented type of trafficking in aggregate statistics. In comparison, other forms of exploitation are less reported: forced labor, domestic servitude, forced marriage, organ removal, and exploitation of children in begging.

In the fourth point, it emphasizes a first document on a disproportionate number of women, who are involved in human trafficking not only as victims, but also as traffickers. Offenders have a more prominent role in current slavery than in most 
other forms of crime. This needs to be addressed, especially in cases where former victims have become traffickers.

In the last point, UNODC notes that most national or regional trafficking is carried out by persons whose nationality is the same as their victims. There are also notable cases of long-distance traffic. Europe, for example, is the destination of the victim of the greatest variety of origins, while the victim of Asia is trafficked to the widest range of destinations. The Americas, on the other hand, both origin and destination of victims in human trade are prominent (UNODC, 2009, p. 6-7).

According to UNODC (2009), States' response to trafficking data is only an indirect indicator of the nature of the underlying problem. Countries with wellendowed criminal justice agencies may show an activity of great importance, even when trafficking in human beings is relatively rare, while other countries with major problems, but are no longer able to meet a proportionate response.

UNODC (2009) shared human trafficking data on an important global basis, which will produce valuable information, despite the inherent limitations of criminal justice figures in the world. At least UNODC work has responded to the Protocol to Prevent, Suppress and Punish Trafficking in Persons. From December 2003 to November $2008,63 \%$ of the 155 countries and territories covered by this report had passed laws against trafficking in persons addressing the main forms of trafficking and another $16 \%$ passed anti-trafficking laws covering only certain elements of the Protocol (UNODC, 2009, p. 8).

In addition, 54\% of responding countries have established a special antitrafficking policy unit and more than half have developed a national plan of action to deal with this issue. But this legislative framework is very new, and it is notable that 91 of the reporting countries (57\%) had at least one human trafficking process and 73 countries reported at least one conviction. A core of 47 countries reported having made at least 10 convictions per year, and 15 countries made at least five times that number of convictions (UNODC, 2009, p. 8).

UNODC (2009) provided information for the period 2003-2007. These data showed that the efforts of the international community to promote action on trafficking in persons resulted in a huge recent national activity to combat this trade and to improve effects at the same time. The research revealed two related problems. 
The first problem is that some countries are not even collecting basic data, and many are not collecting data in order to facilitate insight into the national situation, much less comply with international comparability standards. The state should be concerned with deepening the details to address the problem and avoiding incidents. The second problem is that although this report addresses the collective global response to trafficking in human beings, the information collected does not show the fundamental issue. This is because of the nature of the information collected that says much less about what it should say in the actual crime fighting activity itself (UNODC, 2009, p. 13).

Countries with the largest amounts of combat activity may be oblivious to their data and far from being representative of coherence, while the appropriate legislative framework varies greatly in the resources available for implementation and the way these resources are directed. In order to combat trafficking in human beings, data must be shared with the same importance as collective efforts in an internationally standardized way. The content of information from so many different perspectives can offset many of the shortcomings of the data itself.

This information is vital, in the case of a world of limited resources, whose efforts can be focused with maximum effect. According to UNODC (2009), many countries have data and are willing to share. In addition to documenting substantial commitment, a wide range of countries have cut short the trade of people, providing some modest but fundamental knowledge in the hidden world of human trafficking. Institutionally speaking this collection of information in ongoing cooperation program is similar to this drug venture or is used to monitor the implementation of the Traffic Protocol, within the framework of the United Nations Transnational Conference, Organized Crime Convention, is clearly a possibility and potentially invaluable (UNODC 2009, p. 13).

A second Global estimate of forced labor by the International Labor Organization (ILO) was released in 2014 that nearly 21 million people have been victims of forced labor and sexual exploitation. About 11.4 million women and girls, and 9.5 million men and boys participated in forced labor and sexual exploitation. Nearly 19 million victims are exploited by individuals or businesses, and more than 2 million by state or rebel groups. 
Of those exploited by individuals or businesses, 4.5 million are victims of forced sexual exploitation. Forced labor in the private economy generates $\$ 150$ billion in illegal profits per year. Domestic work, agriculture, construction, manufacturing and entertainment are among the most worrying sectors. Migrant workers and indigenous peoples are particularly vulnerable to forced labor. The other, International Labor Organization (ILO) estimate between 2012 and 2014 made a difference that did not decrease the number of victims but increased. The International Labor Organization (ILO) estimate, (2017),

At any time in 2016, about 40.3 million people are in modern slavery, including 24.9 in forced labor and 15.4 million in forced marriages. This means that there are 5.4 victims of modern slavery per thousand people in the world. 1 in 4 victims of modern slavery are children. Of the 24.9 million people trapped in forced labor, 16 million people are exploited in the private sector, such as housework, construction or agriculture; 4.8 million people in forced sexual exploitation and 4 million people in forced labor imposed by state authorities. Women and girls are disproportionately affected by forced labor, representing $99 \%$ of victims in the commercial sex industry and 58\% in other sectors (ILO, 2017, p.1).

The UNODC Global Report, (2016), trends in forms of exploitation among victims of trafficking detected (2007-2014).

Table 1 - Forms of exploitation in human trafficking.

\begin{tabular}{l|l|l|l|l|l|l|l|l|} 
Year & $\mathbf{2 0 0 7}$ & $\mathbf{2 0 0 8}$ & $\mathbf{2 0 0 9}$ & $\mathbf{2 0 1 0}$ & $\mathbf{2 0 1 1}$ & $\mathbf{2 0 1 2}$ & $\mathbf{2 0 1 3}$ & $\mathbf{2 0 1 4}$ \\
\hline $\begin{array}{l}\text { Percentage Estimate } \\
\text { Traffic to other forms }\end{array}$ & $\%$ & $\%$ & $\%$ & $\%$ & $\%$ & $\%$ & $\%$ & $\%$ \\
$\begin{array}{l}\text { Trafficking for sexual exploitation } \\
\text { Trafficking in labor }\end{array}$ & 32 & 31 & 34 & 31 & 40 & 38 & 39 & 38 \\
\cline { 2 - 10 } & 59 & 61 & 58 & 57 & 53 & 56 & 53 & 54 \\
\cline { 2 - 10 } & 9 & 8 & 8 & 12 & 7 & 6 & 8 & 8 \\
\hline
\end{tabular}

Source: Adapted from UNODC (2016, p. 10).

To a more comprehensive understanding of human trafficking, it is needed to face local context and history. Related to East Timor it is relevant to point out that in the early fifteenth to nineteenth centuries, the Timorese woman faced difficult problems with respect to freedom. According to Belo (2016, p. 2), at this time there was no opportunity for Timorese women to participate in open society activities. They lived alone in the house, in the Villages. Those who went out were assigned to serve the soldiers and rulers, in total submission. The man had power in his hands, and the women had only the task of rearing children and caring for housework. 
In the Japanese invasion and occupation, during World War II, (1942-1945) many Timorese women were subjected to serve the soldiers. There is still no statistic of how many East Timorese women and girls were taken and sold to other countries by the occasion of that war. The Japanese have not yet acknowledged how many violations the military practiced against the dignity of Timorese women, at that sad moment in the country's history, but the victims continue to claim their rights.

With regard to the occupation of Indonesia, violations occurred over 24 years (1975-1999). In this period, according to Belo (2016), women who fought the invaders suffered the most, some were arrested and tortured, others raped, and many women and girls were victims of sexual violence by the military.

East Timor is a relatively new country, since 2002, and still characterizes itself as a poor country, has been seeking to defend the dignity of its citizens as its main wealth. However, there are vulnerabilities in the country related to ecology, economics, social organization and culture. This makes it easier for situations like human trafficking to become a nightmare for part of the population.

In East Timor in the Constitution Democratic Republic of East Timor (CDRET), Title II, talks about rights, freedoms and personal guarantees and in 29 article states: "Right to life", human life is inviolable, the state recognizes and guarantees the right to life and there is no penalty of death (EAST TIMOR , 2002, Tt 3, s.29)

According to the UNODC report (2009, p. 187) on East Timor, the specific offensive of human trafficking was established in 2003. Moreover, the Department of Migration, which is responsible for the investigation of immigration crimes, presents the report in 2006, where four men and one woman were investigated, arrested and prosecuted for trafficking in persons and two men and eight women investigated were arrested and prosecuted in 2007. No action was registered before 2007, although the International Organization for Migration (IOM) trafficking of a girl for sexual exploitation in 2006. In these cases, NGOs and international organizations provided medical and psychosocial support, return services and recovery reintegration for victims of trafficking.

According to Grayley (2016, p. 1), the efforts of the Timorese Government to combat and control human trafficking led East Timor to improve its classification in the annual report of the US Department of State on trafficking in persons. The State 
Department welcomes East Timor's "reactivated efforts to combat human trafficking" over the past year, noting that "building the partnerships and networks necessary to combat human trafficking, protects victims and prosecutes perpetrators"

Despite the improvements, the 2016 report stresses that East Timor continues to be a source and destination for men, women and children subjected to forced labor and sex trafficking. Occasionally, young men from rural areas are attracted to the capital with the promise of better prospects of employment or education and are in some cases victims of sexual trafficking or domestic servitude (GRAYLEY, 2016, p. 1).

The same author (2016, p. 1) reports that there was at least one case of a village chief involved in this type of trafficking. The report points to organized crime in Indonesia and China as sex trafficking in East Timor.

\section{The concern of Catholic Church}

The theme of human trafficking is present in recent Church's documents as part of its social thought, with a wide range of Church Magisterium documents, such as the Second Vatican Council, the Catechism of the Catholic Church and the Papal Encyclicals, which propose various paths to promote and defend the dignity of the human person. The Social Doctrine of the Catholic Church begins in a more systematic way with the encyclical Rerum Novarum (RN) of Pope Leo XIII (1891), where he shows his preoccupation with social life, respect and appreciation of human dignity. But it was in the Second Vatican Council (1965) that the Church showed for the first time the specific concern about human trafficking as a serious crime.

As we have said, the attention of the Church to social life begins with RN, where the response of the Church to the questions of justice and the defense of workers arises. This fact is justified by the wages of workers, labor rights, private property and objectifying against the Marxist-Communist idea. One notes, then, the voice of duty of the Church, to build social justice. Forty years later, Pope Pius XI's Encyclical Quadragésimo Anno (QA) (1931) came. This Encyclical seeks to defy the economic policies of the time, exposing the roots of its chaos, as well as offering a solution for the reform of the social order of life. It should not be forgotten that the RN, which talks about personal rights and common property, capital and labor, principles of fair 
sharing, fair wages, principles of economic recovery and social order, discusses socialism and, of course, capitalism in the footsteps of Church to overcome structural poverty. The Encyclical Mater et Magistra (MM) of Pope John XXIII (1961), talks about Christianity and social progress. For the first time, through a document of the Church, the "international" question of justice was mentioned. There is a great chasm between rich and poor countries. Poverty in Asia, Africa, and Latin America is a product of an unjust system in the world order. This Encyclical is still associated with the RN's warning, and at the beginning of the $M M$ it is reminded once again of the spirit of RN and QA. According to the newest emerging issues in the social, political and economic fields, we see the changes. Pope John XXIII's (1963) document Pacem in Terris (PT) talks about the end of the war, the arms race and the importance of strengthening international relations through established institutions such as the United Nations. This document has a didactic content, destined not only to the Catholic Church, but also to all in general.

The document Vatican Council II (1965) was a landmark for the renewal of the general life of the Catholic Church. Gaudium et Spes (GS) places great concern on the subject of the relationship between the Church and the modern world. For the subject studied the most important citation in GS No. 27, where the Catholic Church appealed to the whole world for the concerns of human trafficking, conceptualizing as a serious crime.

Slavery, prostitution, the sale of women and children, and poor working conditions, in which men are treated more as a means of income and not as free and responsible, abhorring that it is the poison that pollutes society, the degrading offenders and is the greatest insult to the Creator (GS, 27).

It is noted that the document refers to "selling women and children", and the term human trafficking, will only appear later. This issue returns in another passage of the document, inserting the problematic between the aggressions and the human dignity:

In addition, everything that opposes life itself, such as any kind of murder, genocide, abortion, euthanasia, or intentional self-destruction, violates the integrity of the human person, such as mutilation, torments inflicted on the body or mind, tries to coagulate his own will. Any aggression against human dignity, such as arbitrary arrest, deportation, slavery, prostitution, sale of women and children and others, are treated as mere instruments of commerce and not 
as free and responsible persons. This all poisons human society. Moreover, they are wholly against the law of the Creator (GS, 27).

The Church's teaching on the subject continues in the Encyclical of Pope Paul VI Populorum Progressio (1967) (PP), which talks about the progress of nations. The Church, according to the document, considers this subject only as a relation between economic, technological and cultural issues. The issue of the marginalization of the poor is under pressure in this document. The development of humankind today finds it difficult to cooperate among nations, in the support of international organizations, and in global agencies that provide food aid, whose event is headed towards peace.

The document Octogesimo Advenines (1971)(OA), by Pope Paul VI, is an apostolic letter destined to mark the age of 80 years of RN. This document invites all members of the Church to act against poverty. Problems related to urbanization are seen as one of the causes of the birth of the "new poverty" as a poor country and community groups living in the suburbs. It also addresses issues of discrimination in skin color, origin, culture, sex, and religion. The Church encourages its people to act actively on political issues and insist on striving for values to evangelize the people. The light of truth will be a certainty or uncertainty of the phenomenon of the advancement of humanity related to justice, urbanization and its consequences, discrimination of rights in general.

In the Encyclical Evangelium Vitae (EV), Pope John Paul II (1993) took up the question of the 'trade of women and young people' as something that opposes life:

All that is opposed to life, such as all kinds of murder, genocide, abortion, euthanasia and voluntary suicide, and everything that violates the integrity of the human person, such as mutilation, bodily and mental torment, and attempts to own consciences, everything that offends the dignity of the human person, such as living conditions, infrastructure, arbitrary detention, deportation, slavery, prostitution, trade in women and young people, and degrading conditions of work, are treated as mere instruments of profit and not of freedom and responsibility $(E V, 3)$.

Veritatis Splendor (VS) $\mathrm{n}^{\circ} 80$ indicates the importance of the subject on all elements exposed to error, whose element of Church teaching needs perhaps the strongest defense against current theories. Thus, the Pope describes the nature of these objects that "radically contradict the good of the person" and are "intrinsically 
evil". In this way, the Pope directly cites from Vatican II cases of acts that, according to their species, offend the integrity of the life of the human person:

Everything that is opposed to life, [...] the commerce of women and youth, and also the degrading conditions of work, in which the workers are treated as objects and not as free and responsible people. All these and similar things are controversial, these actions corrupt human civilization and dishonor those who do so (VS, 80).

The Church understands that God created the human being as protector and offered him the possibility of cultivating and safeguarding his work. The continuity of God's work is part of human work. The consideration of this fact is truly a gift and a duty. The human being has his own dignity and valorization of his work not as a commodity but as a responsibility. According to Pope Francis (2014), the Holy See expresses its appreciation of the contribution made by the International Labor Organization (ILO) to the protection of the dignity of human work in the context of social and economic development and through debate and cooperation among governments, workers and the employers. To promote the dignity of workers, efforts are needed everywhere for the common good of all (FRANCIS, 2014, p. 1).

Unemployment continues to tragically widen the frontiers of poverty. This is particularly disheartening for unemployed young people, who are easily discouraged from becoming demoralized, losing awareness of their value and feeling alienated from society.

Pope Francis (2014, p. 1) quoted Evangelii Gaudium n. 192, and says that it is necessary to commit to increasing job opportunities, to confirm the conviction that only "in free, creative, participative and supportive work, the human being expresses and enhances his own dignity". The message of Pope Francis at the International Labor Organization (ILO) in Geneva in 2014 spoke about another serious problem that refers to the mass migration that the world must face. It is already remarkable the "number of men and women who are forced to look for work far from their own country and this is cause for concern". They do not expect a better immediate future often find misunderstanding and exclusion, not to mention the occasions on which they experience tragedies and disasters. After they face such sacrifices, they often fail to find decent work and thus become victims of a certain "globalization of indifference". 
Thus, their situation shows other dangers, such as the horror of trafficking in human beings, forced labor, and the reduction of slavery (FRANCIS, 2014, p. 1).

In this way, Pope Francis, places the problem of human trafficking in the context of the degradation of working conditions. In the Message for the World Day of Migrants and Refugees, the pope points out that it is unacceptable that in today's world, the work carried out by slaves has become currency. This can't continue like this! One scourge and one crime against the whole of humanity is trafficking in human beings. From families individually to the world community, joining forces and working together to free the victims of such trafficking eradicate this crime (FRANCIS, 2014, p. 1).

According to Pope Francis (2014, p. 2), the time for cooperation and new paths to strengthen and increase solidarity has arrived. This requires a renewed commitment to the dignity of each person, a more determined realization of international standards on work, planning for human-centered development as the central and primary beneficiary, a new assessment of the responsibilities of multinational corporations, in the countries where they are located, including the profit and investment management sectors, and a coordinated effort to encourage governments to facilitate the transfer of migrants for the benefit of all, thereby eliminating trafficking in human beings and dangerous conditions of travel.

Pope Francis also says that effective cooperation in these fields will be greatly favored by the definition of future sustainable development goals. As he recently expressed to the Secretary-General and to the Executive Heads of the United Nations:

The future objectives of sustainable development should be formulated with generosity and courage so that they can effectively address the structural causes of poverty and hunger and to ensure decent work for all and adequately protect the family, an essential element of any sustainable economic and social development (FRANCIS, 2014, p. 2).

The social doctrine of the Catholic Church is in favor of the initiatives taken by the ILO, which aim to promote the dignity of the human person and the nobility of work. Pope Francis (2014, p. 2), encouraged the ILO in its efforts to meet the challenges of the contemporary world, remaining faithful to these noble purposes. At the same time, the Pope says: "I invoke the blessing of God on all that you carry out, to safeguard and increase the dignity of work, for the common good of the human family". 
In Brazil, the issue of human trafficking was a central theme of the 2014 Fraternity Campaign, a national campaign organized by the Brazilian National Bishops' Conference (CNBB). In this campaign, the Church demonstrates solidarity with people affected by human trafficking, committed to defending the dignity of the person, fundamental rights and the eradication of crime. This crime is seen as a radical denial of God's plan for humanity.

\section{Final considerations}

Victims involved in trafficking are women and men, adult and children. It is a great problem of our time, since more than 40 million people in world is in this modern slavery. The problem is composed in many dramatic aspects, being the sexual exploitation one of the most related. Among the difficulties to address this issue is that many promoters are socially very well established, it means that its main motivation is economic, since forced labor in the private economy generates billions in illegal profits per year.

The issue of human trafficking in East Timor is like in many countries, is it formally forbidden but there are not effectives actions to prevent, combat and condemn it. There are as well local people involved as victims and as traffickers, and among these there are persons with social and local leadership.

The Catholic Church brought the question of human trafficking more clearly in the Vatican II Council denunciating what was initially called "trade of women and children". The Pope John Paul II situated the "trade in women and young people" among the actions opposed to life and that "violates the integrity of the human person". In these statements the Church points out that human being is treated are mere instrument of profit. Pope Francis has been situating this question in the context of actual works conditions as well in the context of migrations and refugees. He addresses the problem as "trafficking in human beings" and points it out as "crime".

The growing concern of the Catholic Church about trafficking in human express diverse and complex perspectives about this issue: it is an attempt to human dignity, a crime, an exploitation, a result of bad work condition impacted over those who are living in poverty on earth. 
The future objectives of sustainable development should be formulated with generosity and courage so that they can effectively address the structural causes of poverty and hunger and that they achieve substantial further results in favor of preserving the environment and ensure decent work for all and adequately protect the family, an essential element of any sustainable economic and social development.

\section{References}

BELO, C. F. X. Women in Society and in the Church - A contribution to the Reflection on the Dignity of Women. 2016. Available at: <http: //forum-haksesuk.blogspot.com.br/2016/03/ thewoman-in-society-and-the-church-um.html>. Access in: 01 dec. 2018.

CAZARRÉ, M. European Parliament says 21 million people are victims of trafficking in the world. 2016. Available at: <http://agenciabrasil.ebc.com.br/internacional/noticia/201610/parlamento-europeu- say-that-21-million-of-people-are-victims-of $>$. Access in: 01 dec. 2018.

UNIC. Universal Declaration of Human Rights, 2009. available at: <http://www.onu.org.br/img/2014/og/DUDH.pdf>. Access in: 01 dec. 2018.

FRANSCISCO. (2014). The Message by Occasion of the $103^{\text {rd }}$ session of the International Labor Organization (ILO) conference. 2014. Available at: <http://w2.vatican.va/content/francesco/en/messages/pont-messages /2014/documents/papa-francesco_20140522_messaggio-ilo.html>. Access in: 01 jan. 2019.

GRAYLEY, M. V. IOM - International Organization for Migration. New York: UN Radio, 2016. Available at: <http://www.unmultimedia.org/radio/portuguese/2016/07/programa-decapacitacao-da-oim-quer-combater-trafico-em-timor-leste/ \#WbfnBfmGPIU>. Access in: 01 aug. 2018.

IDH. East Timor Human Development Index. 2016. Available at: <https://pt.actualitix.com/pais/tls/timor-leste-indice-de-devolvimento-humano.php >. Acesso em: 01 dec. 2018.

ILO - INTERNATIONAL LABOR ORGANIZATION. Global Forced Labor Estimate. 2014. Available at: $\quad$ http://www.ilo.org/sapfl/Informationresources/ILOPublications/WCMS_181953/langen/index.htm>. Access in: 01 aug. 2018.

ILO - INTERNATIONAL LABOR ORGANIZATION (2017). Global Forced Labor Estimate, available at: <http://www.ilo.org/global/topics/forced-labour/lang--en/index.htm>. Access in: 01 aug. 2018.

PAULO, J. II. Veritatis Splendor. 1993. Available at: <http://w2.vatican.va/content/john-paulii/en/encyclicals/documents/hf_jpii_enc_06081993_veritatis-splendor.html>. Access in: 01 dec. 2018. 
PAULO, J. II. Evangelium Vitae. 1995. Available at: <http://w2.vatican.va/content/john-paul- ii / encyclicals / documents / hf_jp-ii_enc_25031995_evangelium-vitae.html>. Access in: 01 jan. 2019.

UNODC - UNITED NATION OFFICE ON DRUGS AND CRIME. Global Report on Trafficking in Persons. 2009. Available at: <http://www.unodc.org/unodc/en/human-trafficking/globalreport-on-trafficking-in-persons.html>. Access in: 01 aug. 2018.

UNODC - UNITED NATION OFFICE ON DRUGS AND CRIME. Global Report on Trafficking in Persons. 2016. Available at: https://www.unodc.org/documents/data-andanalysis/glotip/2016_Global_Report_on_Trafficking_in_Persons.pdf. Access in: 01 aug. 2018

VATICAN, II. Gaudium et Spes. 1965. Available at: <http://www.dhnet.org.br/direitos/anthist/marcos/edh_enciclica_gaudium_spes.pdf >. Access in: 01 dec. 2018.

EAST TIMOR. Constitution of the Democratic Republic of East Timor. 2002. Available at: <http://timor-leste.gov.tl/wp-content/uploads/2010/03/Constitution_RDTL_ENG.pdf>. Acess in: 01 may 2020.

RECEBIDO: 20/05/2019

APROVADO: $11 / 04 / 2020$
RECEIVED: 05/20/2019

APPROVED: 04/11/2020 